\title{
МЕДІАЦІЯ У СПОРАХ ЩОДО ОХОРОНИ ЗДОРОВ'Я
}

\begin{abstract}
ТОКАРСВА Ксенія Сергї̈вна - кандидат юридичних наук, доцент кафедри конституційного і адміністративного права, Національний авіаційний університет https://orcid.org/0000-0001-5705-5211 DOI 10.32782/NP.2020.4.7
\end{abstract}

Статья посвящена медиащии в спорах, которье возникают в сбере здравоохранения между пациентом и врачом, учреждением здравоохранения. В исследовании использованъ системно-структурнвй, сравнительно-правовой методъ, метод прогнозирования, анализа и синтеза. Анализ научной периодики и публикащий в средствах массовой информаичи позволил определить современное состояние и перспективъ использования медиации в медищинских спорах. Проанализированъ особенности врачебной ошибки и споров в сбере здравоохранения в иелом. Проведенное исследование позволяет утверждать о наличии двух способов защить прав субъектов медицинского спора: судебного и внесудебного. Установлен перечень основньх внесудебнъх альтернативнъхх способов разрешения споров, используемьхх в спорах в сбере медицинь: обращение в въишестоящий орган, переговорь, медиачия и арбитраж. Охарактеризованъ альтернативнъие способъ разрешения споров и проанализирован опьт их применения в медицинских спорах зарубежнылми странами. Установлено, что медиачия является наиболее распространеннълм и эбббективныл способом урегулирования конбликтов в отношениях «врач-пачиент». Определенъ преимущества посредничества в таких спорах. Отмечено актуальность медиачии для сберь охранъ здоровья, учитьлвая ее конфиденциальность. Сделан въгвод, ито соглашение по результатам медиации между пациентом и врачом будет иметь высокий уровень исполнения, учитьлвая взаимнъии интерес сторон.

Ключевые слова: медиачия, здравоохранение, врачебная ошибка, медичинский спор, альтернативное разрешение споров.

\section{Постановка проблеми}

Недосконалість підготовки медичного персоналу, недостатне матеріальнотехнічне забезпечення закладів охорони здоров’я, «людський фактор» - усе це зумовлює зростання рівня поширення такого негативного явища як «лікарська помилка». У світі спостерігається тенденція зростання кількості спорів між пацієнтами та лікарями і медичними закладами. Сучасний виклик, пандемія COVID-19, вимагає від лікарів не лише виконання своїх обов'язків, а й намагань знизити рівень соціального напруження. Судовий розгляд діє за принципом «переможець-переможений», тому суд не в змозі задовольнити інтереси обох сторін одночасно. Натомість альтернативні способи вирішення спорів як нові способи врегулювання конфліктів у суспільстві демонструють високу ефективність як у приватно-правовій, так і публічно-правовій сфері суспільних відносин. 3 огляду на актуальність пошуку шляхів налагодження діалогу між пацієнтами та медичними працівниками, варто дослідити медіацію як універсальний інструмент вирішення спорів. 


\section{Адміністративне право}

\section{Стан дослідження}

Проблеми застосування медіації як засобу ефективного регулювання спорів досліджували у своїх працях вітчизняні науковці, зокрема Сидєльніков О.Д., Грень Н.М., Шинкар Т.I., Корінний С.О., Крестовська Н.М., Мазаракі Н.А. та інші, але вказаними вченими залишилось не розглянуте питання особливостей врегулювання конфлікту внаслідок лікарської помилки та спорів вирішення спорів за допомогою медіації у сфері охорони здоров’ я в цілому.

Метою дослідження $є$ особливості застосування медіації до спорів, які виникають у сфері охорони здоров'я.

Для досягнення поставленої мети дослідження було використано сукупність сучасних загальних та спеціальних методів наукового пізнання. За допомогою методів класифікації, групування, синтезу та системно-структурного методу було визначено оптимальний перелік альтернативних способів вирішення спорів у відносинах «лікар-пацієнт». Порівняльно-правовий метод сприяв дослідженню зарубіжного досвіду використання медіації та арбітражу щодо спорів у сфері охороні здоров'я. Метод прогнозування використовувався для аналізу особливостей та перспектив використання медіації у спорах щодо лікарської помилки. Аналіз наукової періодики та публікацій засобів масової інформації дозволив визначити сучасний стан та перспективи використання медіації у медичних спорах.

\section{Виклад основних положень}

Спори у сфері охорони здоров'я виникають переважно з приводу надання медичної допомоги, а сторонами таких спорів є лікар та пацієнт. Пацієнт - людина, що одержує медичну допомогу, піддається медичному нагляду та (або) лікуванню 3 приводу певного захворювання, патологічного стану чи іншого порушення здоров'я та життєдіяльності, або користується медичними послуги незалежно від наявності захворювання [1, с. 61].
Медичні спори виникають внаслідок неконструктивної комунікації між лікарем та пацієнтом, що спричинено негативним досвідом пацієнта або упередженим ставленням сторін один до одного. Однак найбільшу увагу привертають спори, що виникають у випадку вчинення лікарської помилки.

Лікарська помилка - це подія, яка сталася або могла статися за певних умов, викликана невинними діями, бездіяльністю або несвоєчасними діями лікаря (або молодшого медичного персоналу) при наданні пацієнту медичної допомоги або медичних послуг, що в результаті спричинила хоча 6 одну несприятливу для пацієнта подію: смерть; заподіяння істотної шкоди здоров'ю пацієнта (наприклад, поява нового патологічного процесу); виникнення нестерпних больових відчуттів або інших страждань; підвищення рівня ризику смерті; відсутність очікуваного потенційно досяжного результату тощо [2, с. 59].

Серед ознак, притаманних лікарській помилці, які не кримінуються як службова недбалость, Р. І. Аемеха визначає такі:

- дії лікаря відповідають чинному законодавству та професійним нормам у сфері медицини;

- добросовісна омана;

- існування об'єктивних причин добровільної омани (наприклад, відсутність необхідних технічних засобів);

- важкі об'єктивні умови праці (наприклад, перевтома лікаря);

- неможливість лікаря передбачити негативні наслідки [3, с. 106].

3 огляду на поширення спорів між лікарями та пацієнтами, особливо актуальним стає питання захисту прав суб'єктів у сфері охорони здоров'я. Основними способами захисту прав пацієнтів та лікарів слід визначити судовий та досудовий. Для українського суспільства традиційним способом є відновлення порушених прав шляхом звернення до суду, однак судовий розгляд зрідка задовольняє справжні інтереси сторін. У зв'язку з неефективністю судової системи поширюються відносно нові альтернативні способи вирішення спорів, у тому числі медичних. 
Найбільш активний розвиток альтернативні способи вирішення спорів отримали у США. Щороку внаслідок лікарських помилок у державі помирає близько 150 тис. пацієнтів, тоді як 30 тис. отримують серйозні травмування [4, с. 495]. Позасудовими способами вирішення медичних спорів у США є: програма раннього відкриття інформації та вибачень (early apology and disclosure programs), за допомогою якої вдається уникнути до 67\% звернень до суду; медіація, яка дозволяє мирно вирішити медичний спір у $90 \%$ випадків; арбітраж, який вважається менш ефективним способом, ніж медіація, однак більш дієвий, ніж традиційний суд, за швидкістю розгляду та витратами [5].

Тож, окрім звернення до суду загальної юрисдикції та Европейського суду з прав ^юдини, способами захисту прав пацієнта визначають: звернення до органу з захисту прав споживачів, звернення до омбудсмена, звернення до громадських організацій, залучення медіатора, звернення до третейського суду, подання скарги у адміністративному порядку [6, с. 110].

Найпростішим та найдоступнішим вирішенням конфліктів 3 приводу надання медичних послуг вважається звернення до керівника медичного закладу, яке відбувається без оформлення будь-яких процесуальних документів, без залучення третіх осіб та не дотримуючись ніяких процедур. За процесуальними ознаками таке звернення відповідає ознакам альтернативного способу врегулювання конфліктів - переговорів. Під час розв'язання конфлікту між лікарем та пацієнтом важливо врахувати умови та причини виникнення такого конфлікту, а саме: чи залучено особисті відносини, чи може мати місце конкретне порушення прав людини. Переговори можуть бути проведені пацієнтом із головним лікарем, завідуючим відділенням або іншим законним представником. На думку В. О. Галай, фактично будь-яка проблема, яка виникає у пацієнта протягом перебування в медичному закладі, може бути врегульована головним лікарем [7, с. 70].

На нашу думку, переговори у спорах 3 приводу надання медичних послуг є ефек- тивним механізмом лише у випадках нескладних особистісних конфліктів, наприклад, у випадку неповаги з боку медичного персоналу. Однак, якщо спір стосується лікарської помилки, яка спричинила значні негативні наслідки, потребує матеріального та морального відшкодування, вирішення такого спору без залучення додаткових способів захисту та відновлення порушених прав лише посилить напругу між сторонами та призведе до затяжкого судового розгляду.

Якщо переговори не надали бажаного результату на сьогодні в Україні наступним кроком для пацієнта є оскарження неправомірного рішення, дії або бездіяльності лікаря шляхом звернення усно або письмово до Інспекції з питань захисту прав споживачів, регіональних управлінь Міністерства охорони здоров'я України, Національної служби здоров'я України та подання заяви про проведення клініко-експертної комісії [8]. Механізм оскарження неправомірних рішень або дій медичних працівників є досить розвиненим. Але такий спосіб не передбачає контролю сторонами процесу вирішення спору, тому не гарантуе задоволення потреб пацієнта та не виключає можливість звернення до суду.

Звернення до омбудсмена використовується у тих державах, де повноваження у сфері медіації надано посадовим особам, які контролюють дотримання прав та інтересів громадян. Арбітраж, який широко використовується щодо спорів між лікарем та пацієнтом у СШІА, є більш формальною формою альтернативного вирішення. Зазвичай, сторони залучають адвокатів, які спілкуються 3 арбітром та арбітражною комісією, після чого арбітр виносить обов'язкове рішення у справі. Найбільш популярною формою використання арбітражу у сфері охорони здоров' я є арбітражне застереження. Пацієнти та лікар укладають угоду, відповідно до якої у випадку виникнення спору він буде вирішуватися у арбітражному порядку. Таким чином, лікарі захищають себе від судових розглядів [5].

Як справедливо відзначають В. Поліщук та О. Сєдашова, для більшості людей відносини «лікар-пацієнт» є досить особис- 


\section{Адміністративне право}

тісними та прирівнюються до сімейних. Це пов'язано із емоційним забарвленням таких відносин, хвилюванням пацієнта щодо результатів лікування, вартість лікування тощо. Тобто лікар сприймає спілкування 3 пацієнтом об'єктивно, маючи методи лікування. Тоді як пацієнт має переживання щодо хвороби та суб'єктивне ставлення до відносин із лікарем, що в подальшому виливаються у конфлікти між ними [9].

Зважаючи на таку емоційну забарвленість спорів у відносинах «лікар-пацієнт», найбільш доцільним вбачається застосування до таких спорів медіації.

Медіація у перекладі 3 лат. mediare означає бути посередником. У сучасному розумінні це спосіб вирішення спорів із залученням медіатора, що допомагає проаналізувати конфліктну ситуацію, аби зацікавлені сторони самостійно мали можливість обрати варіант рішення спору, який задовольнив би інтереси і потреби всіх учасників спору [10, с. 12].

Неформальний процес медіації дозволяє обом сторонам безпосередньо брати участь у врегулюванні конфлікту. Аікарі, зокрема, мають можливість висловити розчарування в зв'язку з судовим переслідуванням, коли вони не винні, і описати, як це позначається на їх здатності надавати допомогу іншим пацієнтам. Медіаційні справи надзвичайно ефективні за часом. Відповідно до міжнародної практики, середня тривалість посередництва становить від 1 до 3 днів, а закриття справ від початку до кінця становить від 85 до 165 днів. Для порівняння, вирішення судової справи щодо лікарської помилки нерідко потребує 5 років. Також різко знизилися гонорари адвокатів. Вони відзначили, що їх середній час підготовки до судових розглядів становив 36 годин в порівнянні з 2,5 годинами для посередництва [5]

Головними засадами, на основі яких здійснюється процедури медіації, як визначає О. І. Гузєєв, є:

1) принципи, які характеризують процедуру та особливий статус ії учасників принципи нейтральності та добровільності;

2) принципи, які визначають правила проведення медіації - принципи самостійності, конфіденційності, рівності та співробітництва сторін [11, с. 148].

Кожен із наведених принципів матиме особливе значення у медіації, яка застосовується до спорів у сфері медицини. Щодо принципу нейтральності, то за загальним правилом медіатор повинен бути неупередженим, нейтральним та незалежним. Інакше кажучи, посередник не може бути залежним від сторін спору, органів влади чи третіх осіб, не повинен бути прихильним до однієї зі сторін та не використовувати свої суб’єктивні судження. У випадку виникнення спору між лікарем та пацієнтом нерідко функції посередництва між ними виконує інший лікар або працівник того ж медичного закладу, що збільшує ризики зловживань та суперечить принципу нейтральності медіації. Тому медіатором повинна бути третя особа, яка має відповідну освіту, професійну підготовку з медіації та знання у сфері медицини, що забезпечує надання якісних послуг з посередництва.

Принцип добровільності у медіації полягає у забороні будь-якого тиску на жодну зі сторін спору; прийняття рішення щодо початку та припинення проведення процедури за взаємною згодою сторін; самостійність сторін у виборі медіатора, розпорядженні своїми правами, визначенні обсягу вимог; заборона порушення конституційних прав, свобод та законних інтересів сторін спору та третіх осіб [12, с. 25]. Тож лікар та пацієнт повинні добросовісно домовитися про проведення медіації, маючи щирі наміри на мирне врегулювання конфлікту. Кваліфікований посередник повинен контролювати баланс інтересів протягом процесу медіації. Наприклад, у випадку сильного тиску з боку лікаря та медичного закладу на пацієнта, аби останній пішов на необгрунтовані поступки, медіатор може прийняти рішення про проведення окремих закритих зустрічей зі сторонами або припинити процедуру медіації.

Слід зазначити, що позитивним аспектом $є$ залучення адвокатів сторін до процесу медіації, аби домовленості між лікарем та пацієнтом не виходили за межі права. 
Представники сторін можуть допомогти уникнути будь-яких зловживань у процесі здійснення процедури. Крім цього, навіть невдала медіація, тобто така, що не закінчилась підписанням угоди за результатами медіації, дає сторонам хоча б мінімальне розуміння ризиків та перспектив судового розгляду спору.

Конфіденційність є перевагою для медіації у спорах між лікарем та пацієнтом. Поперше, медіація сприяє вирішенню спору та дотримання лікарської таємниці, тобто нерозголошення відомостей про наявну та перенесену хворобу, результати медичного обстеження тощо, водночас. По-друге, актуальним залишається питання репутації лікаря та медичного закладу. Будь-яка конфліктна ситуація сприяє становленню негативного іміджу. Тому, порівняно з публічним судовим розглядом, посередництво допомагає зберегти багаторічну роботу колективу над репутацією закладу.

Зарубіжний досвід використання медіації у медичних спорах свідчить про їі високу ефективність. Наприклад, в Іспанії цьому сприяє професійна підготовка майбутніх медіаторів: вивчення медіації учнями, бакалаврами, магістрами у навчальних закладах, навчання у соціальних центрах, спеціалізації з медіації у закладах вищої освіти, вимога державного ліцензування та стажування у відповідних закладах. Медіатори у сфері медицини здобувають додаткову підготовку, опановуючи ключові медичні поняття та законодавство у сфері охорони здоров'я. Медичні заклади освіти в Іспанії пропонують майбутнім лікарям відвідувати курси посередництва, де студенти навчаються мирно врегульовувати конфлікти, запобігати їхній ескалації та спілкуватися з пацієнтами [13, с. 16].

У свою чергу, в Італії законодавці з метою поширення медіації встановили певні категорії справ, щодо яких проведення позасудової медіації $\epsilon$ обов'язковим. До цих категорій віднесено спори, зумовлені медичною халатністю та з приводу лікарських помилок. Тобто перед зверненням до суду, сторони медичного спору повинні обов'язково звернутися до медіатора для спроби мирного врегулювання конфлікту [14, с. 79].

Особливий успіх демонструє медіація у сфері охорони здоров'я Китаю. Аише в одній провінції у період 2013-2015 років було проведено майже 5 тис. медіації у спорах «лікар-пацієнт». 3 них успішним укладенням угоди за результатами медіації завершилося $41 \%$, тоді як до суду було передано лише $11 \%$ спорів. В інших випадках сторони відмовлялися від своїх претензій. Китайська модель медіації у сфері медицини включає 4 основних етапи: 1) усі сторони спору роблять заяви; 2) експерти $з$ права та медицини аналізують обставини спору; 3) експерти запрошуються на зустрічі, наприклад, до відділення лікарні; 4) медіатор веде переговори з обома сторонами спору, рунтуючись на думках експертів [15].

Кожна сфера суспільних відносин має специфічні особливості, які вирізняють iii 3-поміж інших та значно впливають на шляхи вирішення конфліктних ситуацій, які виникають у відповідній сфері. Щодо сфери охорони здоров'я, такою особливістю є «асиметричність ролей», оскільки пацієнт виконує призначення лікаря-фахівця. Крім цього, характерними для спору між пацієнтом та лікарем є високе емоційне напруження, недостатність інформації для медіатора щодо стану здоров'я пацієнта, доведення факту наявності або відсутності лікарської помилки та високі ризики для ділової репутації [16].

3 урахуванням вищевикладеного можемо визначити етапи проведення медіації у спірних відносинах «лікар-пацієнт»:1) ініціювання медіації однією зі сторін спору; 2) вибір сторонами медіатора зі списку незалежних осіб, які мають дозвіл на надання послуг посередництва; 3) укладення договору про проведення медіації між пацієнтом і лікарем (медичним закладом); 4) проведення медіації у вигляді спільних або закритих нарад (залежно від ступеня емоційної напруги між пацієнтом та лікарем, особистих побажань сторін); 5) завершення медіації - укладення медіаційної угоди або відмова від медіації будь-кого з учасників процедури; 6) виконання медіаційної угоди у випадку успішності медіації. 


\section{Адміністративне право}

Процес медіації виходить за межі традиційного способів винесення рішення у спорах конфліктуючих сторін. Медіація дає можливість використовувати креативні рішення у складних спорах у сфері охорони здоров'я. Для повної ефективності медіації у сфері медицини повинна досягати кількох цілей: компенсувати пацієнтам завдану шкоду внаслідок необережності лікаря; мотивувати медичні заклади та лікарів покращувати якість своїх послуг та зменшувати кількість лікарських помилок; намагатися зберегти нормальні стосунки між лікарем та пацієнтом; оптимізувати витрати на вирішення спорів [4, с. 516].

На нашу думку, результатом медіації у спорах з приводу лікарської помилки може стати відшкодування матеріальної та моральної компенсації пацієнту, повернення коштів за ті медичні послуги, які не задовольнили пацієнта. Крім цього, доцільним буде усунення лікарської помилки, у тих випадках, де це є можливим. 3 метою усунення лікарської помилки та досягнення угоди 3 пацієнтом медичний заклад може запропонувати пацієнту залучення досвідчених експертів у сфері медицини та безкоштовні медичні огляди.

Позови від пацієнтів щодо компенсації матеріальних та моральних збитків з'являються все частіше. I хоча законодавство щодо правового захисту лікарів та медичних працівників в Україні існує, однак воно не має системного підгрунтя. Тому не лише пацієнт потребує захисту своїх прав, а й лікарі. Якщо лікар працює у державному або комунальному медичному закладі, він не завжди може розраховувати на повноцінний юридичний супровід у розгляді скарг та претензій пацієнтів [1, с. 61]. Тому доступна медіація дозволить у повній мірі висловити свою позицію та відстоювати свої інтереси як пацієнту, так і лікарю, уникаючи бюрократичної тяганини, втрати часу та значних витрат на судовий розгляд.

\section{Висновок}

Таким чином, лікарська помилка є поширеним негативним явищем, яке характеризується нанесення лікарем значної шкоди пацієнту за умови відсутності свідо- мої недбалості. Відносини між пацієнтами та лікарями мають особистісний характер, оскільки стосуються найбільшої цінності людини - їі здоров’я. Спори, які виникають у сфері охорони здоров'я, мають підвищену психологічну напруженість та тісно пов'язані із переживаннями пацієнта про свій стан здоров'я. Запобігти та попередити лікарські помилки можливо за допомогою: налагодження практики конструктивного спілкування пацієнта та лікаря; вміння лікарів слухати, розуміти та інформувати пацієнтів; постійного вдосконалення ними професійних та комунікаційних навичок.

Серед можливих варіантів вирішення спорів у відносинах «лікар-пацієнт» виділяють судовий розгляд та альтернативні способи вирішення спорів. У зв'язку із неефективністю та великою завантаженістю суддів, актуальним $є$ застосування медіації у медичних спорах.

Медіація дає можливість лікарю та пацієнту спілкуватися безпосередньо та самостійно шукати шляхи врегулювання конфлікту та відновлення порушених прав. Медіатор, окрім вищої освіти та підготовки у сфері медіації, повинен володіти знаннями та навичками у сфері охорони здоров'я, щоб розуміти сутність спору та контролювати, аби домовленості сторін не суперечили законодавству у даній сфері. Перевагами медіації над іншими альтернативними та традиційними способами вирішення спорів між лікарем та пацієнтом $є$ добровільність учасників процесу, рівність, самостійність сторін у прийнятті оптимального рішення, нейтральність медіатора та конфіденційність. Конфіденційність допомагає зберегти лікарську таємницю та ділову репутацію лікаря і медичного закладу.

Угода, досягнута за результатами медіації, може включати положення щодо матеріальної, моральної компенсацій, повернення коштів пацієнту та ліквідації лікарської помилки. Існує висока вірогідність виконання домовленостей сторонами, оскільки угода $є$ консенсусом учасників конфлікту. 


\section{Мітература}

1. Іпатов А. В., Гула I. С., Кузьміна $\Lambda$. В., Коробкін Ю. І. Основи правового захисту лікаря і пацієнта. Украӥнсъкий вісник медикосоціальної експертизи. 2018. №. 3-4. С. 60-66.

2. Понкина А.А. Врачебная ошибка в контексте защиты прав пациентов. Москва: Консорциум специалистов по защите прав пациентов, 2012. 200 с.

3. Аемеха P. I. Кримінально-правове значення лікарської помилки. Вісник Аввівського торговельно-економічного університету. Юридичні науки. 2019. №. 8.C. $102-108$.

4. Sybblis S. Mediation in the health care system: Creative problem solving. Pepperdine Dispute Resolution Law Journal. 2006. Vol. 6. Iss. 3. C. 493-517.

5. David H. S., Sonny B. Medical Malpractice Reform: The Role of Alternative Dispute Resolution. Clin Orthop Relat Res. 2012.Vol. 470(5). DOI: 10.1007/s 1 1999-011-2206-2.

6. Дроздова О.В.Диференціація способів і засобів захисту прав пацієнта. Науковий вісник Херсонсъкого державного університету. Серія: Юридичні науки. 2016. №. 1 (1). С. 109-113.

7. Галай В. О. Переговори «пацієнт-лікар» як можливість добровільної співпраці для урегульовання конфлікту. Медичне право України: правовий статус паиієнтів в Украіні та його законодавче забезпечення (генезис, розвиток, проблеми $i$ перспективи вдосконалення): матеріали II Всеукраїнської науково-практичної конференції 17-18 квітня 2008, м. Аьвів. С. 70-73.

8. Пацієнт має право: як оскаржити неправомірне рішення і отримати відшкодування. Міністерство охорони здоров'я України: офіційний веб-сайт. URL: https:// moz.gov.ua/article/health/pacient-mae-pravojak-oskarzhiti-nepravomirne-rishennja-iotrimati-vidshkoduvannja

9. Поліщук В., Сєдашова О. Медіація для медичного бізнесу: менеджмент конфліктних ситуацій. Приватний лікар. 2019. № 5 (38). С. 10.

10. Карташов М. Медіація як форма вирішення корпоративних спорів. Підприємниитво, господарство і право. 2019. №10. C. 11-15.
11. Гузеев А. И. Принципы медиации. Актуальные проблемь современного права и государства. 2015. С. 148-150.

12. Кармаза О. Інститут медіації: основні концепції розвитку. Підприємнищтво, господарство і право. 2017. №. 2. С. 24-28.

13. Демидович О. М. Популяризація медіації як альтернативного способу вирішення медичних спорів: досвід Іспанії. Конфбіктологічна експертиза: теорія та методика: XVII міжнародна науково-практична конференція від 16 лютого 2018 р., Київ, НаУКМА. 2018. С. 15-18

14. Silvestri E. Too much of a good thing: Alternative Dispute Resolution in Italy. Nederlands-Vlaams tijdschrift voor Mediation en confictmanagement. 2017. No. 21. DOI: 10.5553/ TMD/138638782017021004007.

15. Wang M., Liu G.G., Zhao H. The role of mediation in solving medical disputes in China. BMC Health Serv Res. 2020. 20(225). DOI: $10.1186 /$ s 12913-020-5044-7.

16. Радучич О. В. Legal Medical Forum: як жити лікарю в «післяреформових» умовах. Украӥнсъкий медичний часопис. 2019. №3(1). URL: https://www.umj.com.ua/article/157768/legal-medical-forum-yak-zhitilikaryu-v-pislyareformovih-umovah.

Tokarieva K.S.

Candidate of Science of Law, Associate Professor of Constitutional and Administrative Law National Aviation University

MEDIATION IN HEALTH DISPUTES

The article is devoted to mediation in disputes that arise in the field of health care between a patient and a doctor or health care institution. The study uses system-structural, comparative legal methods, methods of forecasting, analysis and synthesis. The analysis of scientific periodicals and publications of mass media allowed to determine the current state and prospects of using mediation in medical disputes. The peculiarities of medical error and disputes in the field of health care in general are analyzed. The study suggests that there are two ways to protect the rights of subjects of medical dispute: judicial and extrajudicial. A list of the main out-of-court alternative dispute resolution methods used in disputes in the field of medicine is established: appeal to a higher body, negotiations, 


\section{Адміністративне право}

\section{АНОТАЦІЯ}

Статтю присвячено медіачї у спорах, які виниканть у сфері охорони здоров'я між паиієнтом та лікарем, закладом охорони здоров'я. у дослідженні використано системно-структурний, порівняльно-правовий методи, метод прогнозування, аналізу та синтезу. Аналіз наукової періодики та публікаиій засобів масової інформациї дозволив визначити сучасний стан та перспективи використання медіаиії у медичних спорах. Проаналізовано особливості лікарської помилки та спорів у сбері охорони здоров'я в иілому. Проведене дослідження дозволяе стверджувати про наявність двох способів захисту прав суб'єктів медичного спору: судового та позасудового. Встановлено перелік основних позасудових альтернативних способів вирішення спорів, які використовуються щодо спорах у сбері медицини: звернення до органу вищого рівня, переговори, медіація та арбітраж. Надано характеристику альтернативних способів вирішення спорів та проаналізовано досвід їх застосування у медичних спорах зарубіжними країнами. Встановлено, що медіачія є найбільш поширеним та еббективним способом врегулювання конфліктів у відносинах «лікар-пацієнт». Визначено переваги посередниитва у таких спорах. Наголошено на актуальності медіаџї для сфбери охорони здоров'я з огляду на їі конфбідениійність. Зроблено висновок, що угода за результатами медіацї між пацієнтом та лікарем матиме високий рівень виконання, враховуючи взаємний інтерес сторін.

Ключові слова: медіація, охорона здоров'я, лікарсъка помилка, медичний спір, альтернативне вирішення спорів. mediation and arbitration. The characteristics of alternative methods of dispute resolution are described and the experience of their application in medical disputes by foreign countries is analyzed. Mediation has been found to be the most common and effective way to resolve doctor-patient conflicts. The advantages of mediation in such disputes are determined. Emphasis is placed on the relevance of mediation to health care given its confidentiality. It is concluded that the agreement on the results of mediation between the patient and the doctor will have a high level of implementation, taking into account the mutual interest of the parties.

Keywords: mediation, health care, medical error, medical dispute, alternative dispute resolution. 